\title{
PREMATURE DISABLEMENT AND DEATH AMONG POST OFFICE WORKERS
}

\author{
BY \\ THE LATE C. G. ROBERTS* AND D. D. REID \\ From the Department of Medical Statistics and Epidemiology, London School of Hygiene and Tropical Medicine
}

From the economic as well as humanitarian point of view, disease which causes premature loss of life or working capacity is of importance and interest. Death before the age of 60 clearly represents a loss to the community of the breadwinner's skill and often entails the burden of the support of his family. The same is true of sickness absenteeism and chronic incapacitating disease which enforces retirement. We are familiar with the use of sickness and death rates in the study of the relations between work, age, and health; less has been written on the importance of the rate of retirement on grounds of ill-health as an index of economic loss and the interaction of work and injury or disease. For these reasons, we here present the results of a survey of the records of disabling illness and premature death among male established staff of the General Post Office during the period 1949 to 1952 inclusive.

\section{Population and Method of Survey}

The established or permanent staff of the General Post Office is not, of course, representative of the national working population. On appointment, employees are subjected to a medical examination designed to exclude those already suffering from certain disorders such as rheumatic heart disease which might reduce their expectation of working life below the usual lower limit of 60 years of age. Their experience thus understates the economic importance of such diseases. On the other hand, complete records are kept of the cause of death or retirement on grounds of ill-health among all men on the permanent establishment of the G.P.O. Particulars of the cause of death were extracted from copies of death certificates submitted in connection with the payment of death gratuities. For members of the staff retired on grounds of ill-health, full clinical particulars, including hospital records where appropriate, are available. The criterion for such retirements is an inability to render regular and effective service, which is likely to be permanent, because of some infirmity of body or mind. This

*Unfortunately Dr. C. G. Roberts died suddenly in Australia just before this paper went to press. At the time of its preparation he was Deputy Treasury Medical Adviser. does not necessarily mean that the retired man is incapable of gainful employment, but only that the Post Office is unable to use his services effectively, since his capacity for work is usually seriously impaired. The decision to retire someone is customarily taken after a period of prolonged sick leave, but there is no fixed total amount of absence at which retirement on grounds of ill-health becomes automatic. Whether a man is regarded as having retired or as having died while still on the staff depends partly on administrative factors in relation to the progress of the disease. The classification of cases into retirements and deaths from certain causes is therefore rather arbitrary, and the two types of wastage must be considered together.

The coding of the causes of death or retirement follows the rules given in the 1948 International Statistical Classification of Diseases, Injuries, and Causes of Death. For deaths, difficulties seldom arose, but certain additional conventions were adopted in dealing with complex cases of retirement in which more than one disease was present. If one of these two or more conditions was, by itself, severe enough to justify retirement, that condition was coded as the cause of retirement. Multiple codings were used in some cases in which no one disease or injury would of itself have been an adequate reason for retirement. Although special inquiries were made if the medical reports left the diagnosis in doubt, no attempt was made to give a more exact coding than the clinical evidence warranted. Thus, if it was not clear whether an observed hypertension was benign or malignant in origin, the condition was coded under "other or unspecified hypertensive disease". Similarly, psychoses could often be classified only under the heading of "other and unspecified mental illness". Nevertheless, we would emphasize that the classification of causes was based not on medical certificates but on reasonably complete and accurate clinical reports.

The population covered by this survey comprises the occupational categories of established staff of the General Post Office employed during the years 1949 to 1952 inclusive for whom accurate age distributions of the numbers exposed to risk were available. They were divided by occupation into six major groups: (1) executive and clerical, (2) postal and telegraph officers and telegraphists, (3) telephonists, (4) postmen higher grade, (5) postmen, and (6) technical officers and technicians. Broadly speaking, the first four groups comprise indoor workers employed on tasks making little demand for 
physical effort. Postmen, and the technicians employed on telephone construction and maintenance work, on the other hand, usually work outside for at least part of the day at tasks which are often physically arduous. The staff can thus be divided into "active" and "sedentary" workers.

Unfortunately, we can make no direct comparison between the death and ill-health retirement rates and the sickness-absence experience of the same population over the same period. We therefore refer, where appropriate, to the more restricted results of a morbidity sample survey conducted among the G.P.O. staff in the London area between mid-1948 and mid-1951. Technicians and technical officers were not included in this sample survey, and the grades of postmen were taken together, but the broad distinction between 'active' and 'sedentary' workers applies well enough for the morbidity data to be useful.

\section{RESULTS}

The general pattern is seen in Table I and Fig. 1, where the age trends of retirement and death rates obtained in this study are compared with the agespecific sickness absence rates found in the London area morbidity survey. All three indices of labour wastage due to injury or disease increase appreciably

TABLE I

ILL-HEALTH RETIREMENT, DEATH, AND SICKNESS ABSENCE RATES

\begin{tabular}{|c|c|c|c|c|c|}
\hline \multirow{2}{*}{$\begin{array}{l}\text { Age } \\
\text { Group } \\
\text { (yrs) }\end{array}$} & \multicolumn{2}{|c|}{ Retirement } & \multicolumn{2}{|c|}{ Death } & \multirow{2}{*}{ 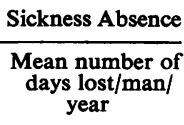 } \\
\hline & No. & $\begin{array}{l}\text { Rate per } \\
1,000 \text { p.a. }\end{array}$ & No. & $\begin{array}{l}\text { Rate per } \\
1,000 \text { p.a. }\end{array}$ & \\
\hline $\begin{array}{l}25-34 \\
35-44 \\
45-54 \\
55-59\end{array}$ & $\begin{array}{r}176 \\
308 \\
1,060 \\
1,209\end{array}$ & $\begin{array}{r}1 \cdot 0 \\
1.8 \\
6.9 \\
20.3\end{array}$ & $\begin{array}{r}79 \\
248 \\
820 \\
645\end{array}$ & $\begin{array}{r}0 \cdot 5 \\
1 \cdot 4 \\
5 \cdot 3 \\
10 \cdot 8\end{array}$ & $\begin{array}{l}11 \cdot 8 \\
14 \cdot 1 \\
17 \cdot 0 \\
22 \cdot 0\end{array}$ \\
\hline Total & 2,753 & $4 \cdot 9$ & 1,792 & $3 \cdot 2$ & \\
\hline
\end{tabular}

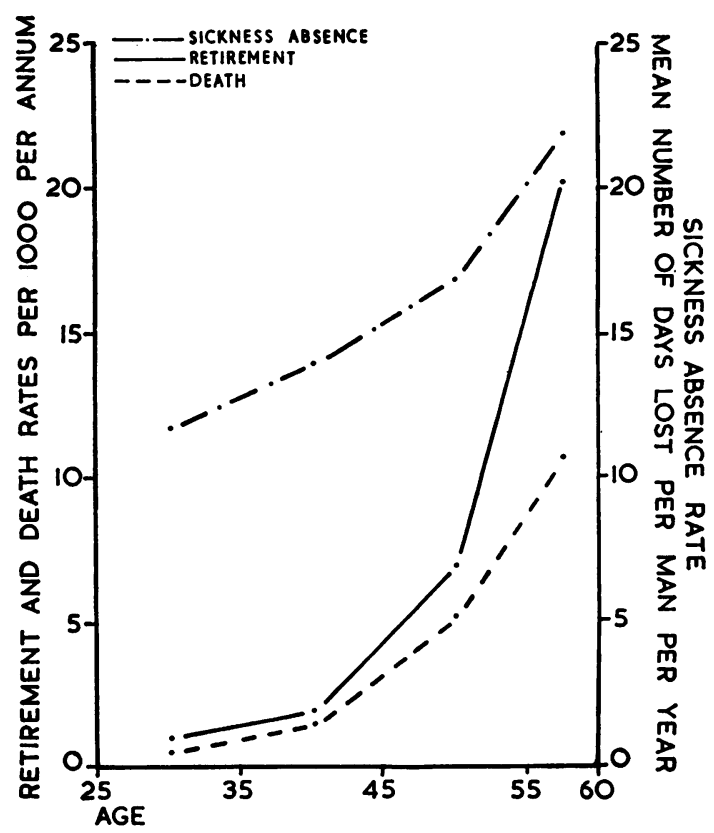

FIG. 1.- Ill-health retirements and deaths (per 1,000 per annum) and mean sickness absences (days per man per annum), by age.

after the age of 45 ; but of the three, the retirement rate appears to be the most sensitive indicator of the effect of ageing on the risk of disabling injury or disease. Further, if the retirement and death rates in each age group be added to give a measure of the total loss to the labour force, a rough calculation shows that, at these rates, some 27 per cent. of men aged 25 would be either dead or disabled before they reach the age of retirement at 60 .

Table II gives a more detailed analysis of the age-specific retirement and death rates according to

AGE SPECIFIC DEATH AND ILL-HEALTH RETIREMENT

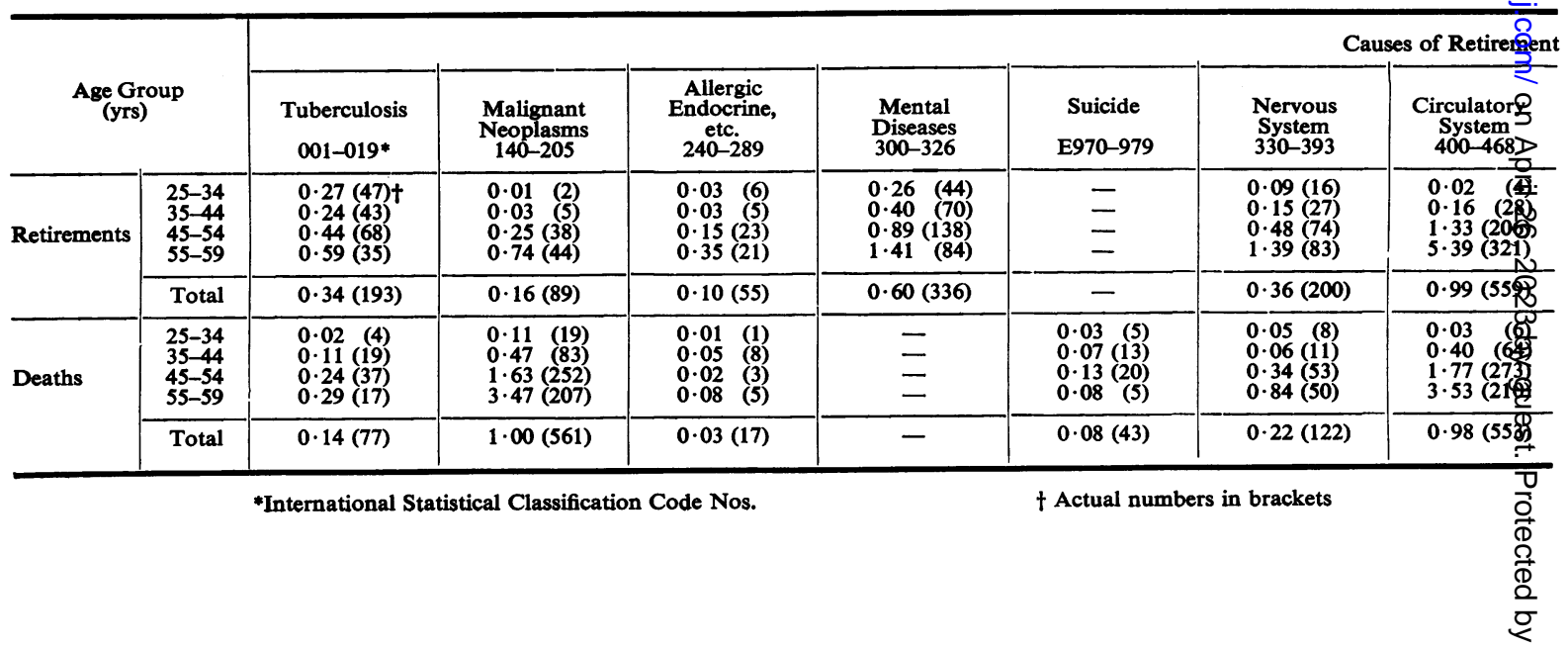


TABLE III

RANKING OF CAUSES OF LABOUR WASTAGE BY TYPE OF DISABILITY

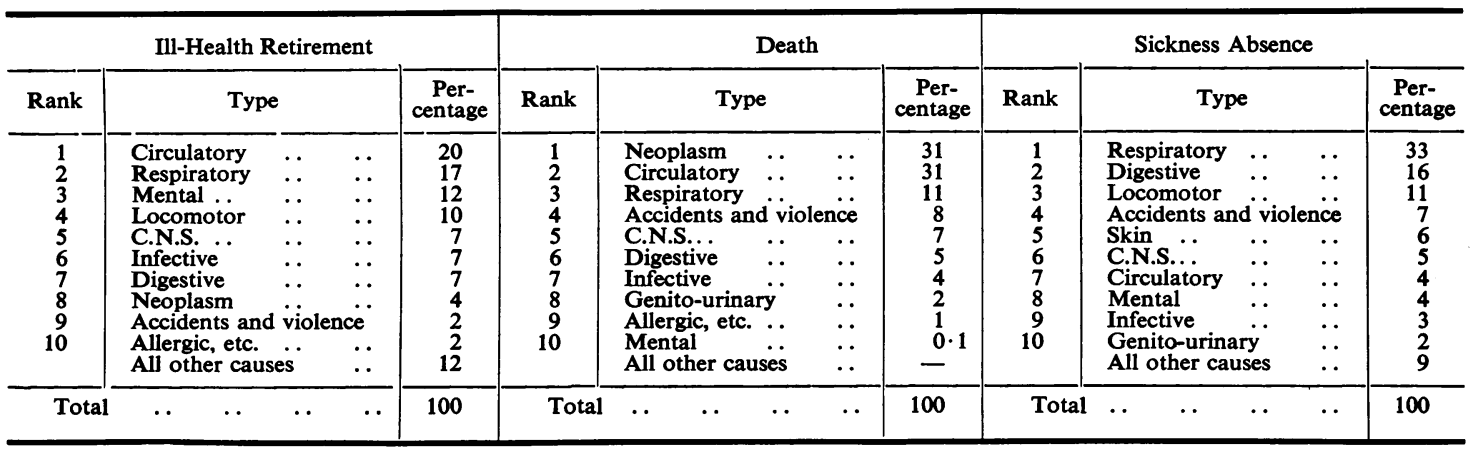

the major divisions of the International List. Based though they are on rather small numbers in any one age and system group, the trends in the rates agree well with general expectations based on national mortality experience. No direct comparison with national death rates is, however, possible, since our experience does not include deaths occurring after retirement. In general, neoplastic disease, partly for the administrative reasons mentioned above, causes death in service rather than retirement and the death rate does therefore give some indication of its incidence. Circulatory and genito-urinary diseases and accidents and violence excluding suicides are about equally likely to cause retirement or death. All the others are, to a varying degree, more often the cause of retirement.

The results of looking at labour wastage from the differing viewpoints of death, retirement, and sickness rates are shown in Table III where the ten numerically most important classes of disability are ranked in order under each heading. It is apparent that neoplastic diseases, which rank high as a cause of death, are of relatively little importance as causes of retirement or of sickness absence. Diseases of the locomotor system behave quite conversely. Diseases of the respiratory and central nervous system alone have similar ranking in all three types of labour wastage.

Each type of disability thus appears to have a different degree of importance depending upon the index of wastage used. Table IV (overleaf) sets out the relative proportions of the total wastage from either death or ill-health retirement for each of the major diseases within these broad groups. It is clear that a relatively few specific disorders (bronchitis, arteriosclerotic and hypertensive cardiovascular diseases, psychoneurosis, tuberculosis, arthritis, and peptic ulceration) are the main cause of ill-health retirement. Cancer, coronary disease, accidents and suicides, and cerebro-vascular lesions, on the other hand, are the principal causes of death among the staff of the Post Office.

RATES BY DISEASE GROUP (Rates per 1,000 per annum)

\begin{tabular}{|c|c|c|c|c|c|c|c|}
\hline $\begin{array}{l}\text { Respiratory } \\
\text { System } \\
\text { 470-527 }\end{array}$ & $\begin{array}{l}\text { Digestive } \\
\text { System } \\
530-587\end{array}$ & $\begin{array}{c}\text { Genito-urinary } \\
\text { System } \\
590-637\end{array}$ & $\begin{array}{l}\text { Locomotor } \\
\text { System } \\
\mathbf{7 2 0 - 7 4 9}\end{array}$ & $\begin{array}{l}\text { Accidents } \\
\text { and Violence } \\
\text { (excluding } \\
\text { suicides) }\end{array}$ & $\begin{array}{l}\text { All Other } \\
\text { Diseases }\end{array}$ & $\begin{array}{l}\text { Multiple } \\
\text { Codings }\end{array}$ & $\begin{array}{r}\text { Total All } \\
\text { Causes }\end{array}$ \\
\hline $\begin{array}{l}0.05 \quad(9) \\
0.18 \text { (31) } \\
1.16(179) \\
4 \cdot 10(244)\end{array}$ & $\begin{array}{l}0.06(10) \\
0.15(27) \\
0.54(83) \\
1.07(64)\end{array}$ & $\begin{array}{ll}0.02 & (3) \\
0.02 & (4) \\
0.05 & (8) \\
0.22 & (13)\end{array}$ & $\begin{array}{l}0 \cdot 06(11) \\
0 \cdot 17(30) \\
0 \cdot 76(117) \\
2 \cdot 10(125)\end{array}$ & $\begin{array}{l}0.02 \text { (4) } \\
0.03 \text { (6) } \\
0.16(24) \\
0.44(26)\end{array}$ & $\begin{array}{l}0.06(10) \\
0.07(13) \\
0.08(13) \\
0.42(25)\end{array}$ & $\begin{array}{l}0.06 \quad(10) \\
0.11 \quad(19) \\
0.58 \quad(89) \\
2.08(124)\end{array}$ & $\begin{array}{ll}1 \cdot 02 & (176) \\
1 \cdot 75 & (308) \\
6 \cdot 86 & (1060) \\
20 \cdot 29 & (1209)\end{array}$ \\
\hline $0.82(463)$ & $0 \cdot 33(184)$ & $0.05(28)$ & $0 \cdot 50(283)$ & $0 \cdot 11(60)$ & $0 \cdot 11(61)$ & $0.43(242)$ & $4 \cdot 89(2,753)$ \\
\hline $\begin{array}{ll}0.05 & (9) \\
0.06 & (10) \\
0.53 & (82) \\
1.51 & (90)\end{array}$ & $\begin{array}{l}0.02(4) \\
0.09(16) \\
0.25(38) \\
0.65(39)\end{array}$ & $\begin{array}{l}0.01 \quad(1) \\
0.01 \quad(2) \\
0.16 \text { (24) } \\
0.12 \quad(7)\end{array}$ & $0.0 \overline{1}(1)$ & $\begin{array}{l}0 \cdot 13(22) \\
0 \cdot 12(21) \\
0 \cdot 22(34) \\
0 \cdot 25(15)\end{array}$ & $\begin{array}{l}0.01 \\
0.02 \quad(1) \\
-\end{array}$ & 二 & $\begin{array}{ll}0.46 & (79) \\
1.41 & (248) \\
5.31 & (820) \\
10.83 & (645)\end{array}$ \\
\hline $0 \cdot 34(191)$ & $0 \cdot 17(97)$ & $0.06(34)$ & $0.00(1)$ & $0 \cdot 16(92)$ & $0.01(4)$ & - & $3 \cdot 19(1,792$ \\
\hline
\end{tabular}


TABLE IV

SPECIFIC DISORDERS AS CAUSES OF ILL-HEALTH RETIREMENT AND DEATH

\begin{tabular}{|c|c|c|c|}
\hline & Disease Group & $\begin{array}{l}\text { Retirements } \\
\text { (per cent.) }\end{array}$ & $\underset{\text { (per cent.) }}{\text { Deaths }}$ \\
\hline $\begin{array}{l}\text { A. Infective } \\
\text { and } \\
\text { Parasitic }\end{array}$ & $\begin{array}{l}\text { 1. Resp. tuberculosis } \ldots \\
\text { 2. Other tuberculosis } \ldots \\
\text { 3. Syphilis } \\
\text { 4. Poliomyelitis } \\
\text { 5. Other } \quad \ldots\end{array}$ & $\left.\begin{array}{l}6 \cdot 54 \\
0 \cdot 47 \\
0 \cdot 07 \\
0.03 \\
0 \cdot 22\end{array}\right\} 7 \cdot 33$ & $\left.\begin{array}{c}4 \cdot 02 \\
0 \cdot 28 \\
- \\
-\end{array}\right\} 4 \cdot 30$ \\
\hline $\begin{array}{l}\text { B. Neo- } \\
\text { plasms }\end{array}$ & $\begin{array}{l}\text { 1. Stomach . } \\
\text { 2. Large intestine } \\
\text { 3. Rectum } \\
\text { 4. Primary of bronchus } \\
\text { trachea and lung.. } \\
\text { 5. Lymphatic and } \\
\text { haematopoietic .. } \\
\text { 6. Other } \quad . .\end{array}$ & $\left.\begin{array}{l}0.36 \\
0.18 \\
0.36 \\
0.36 \\
0 \cdot 22 \\
2 \cdot 07\end{array}\right\} 3 \cdot 56$ & $\left.\begin{array}{r}4 \cdot 52 \\
2 \cdot 06 \\
1 \cdot 28 \\
3 \cdot 85 \\
2 \cdot 12 \\
17 \cdot 52\end{array}\right\} 31 \cdot 36$ \\
\hline $\begin{array}{l}\text { C. Allergic, } \\
\text { Endo- } \\
\text { crine, } \\
\text { etc. }\end{array}$ & 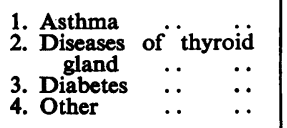 & $\left.\begin{array}{l}0.91 \\
0.22 \\
0.62 \\
0.25\end{array}\right\} 2 \cdot 00$ & $\left.\begin{array}{l}0.33 \\
0.06 \\
0.28 \\
0.28\end{array}\right\} 0.95$ \\
\hline \multicolumn{2}{|c|}{ D. Diseases of Blood etc. } & 0.25 & $0 \cdot 11$ \\
\hline $\begin{array}{l}\text { E. Mental, } \\
\text { Psycho- } \\
\text { neurotic. } \\
\text { etc. }\end{array}$ & $\begin{array}{l}\text { 1. Psychosis: } \\
\text { (a) Schizophrenia } \\
\text { (b) Manic depressive } \\
\text { (c) Paranoid } \\
\text { (d) Other } \\
\text { 2. Psychoneurotic: } \\
\text { (a) Anxiety } \\
\text { (b) Hysterical } \quad \text {. } \\
\text { (c) Neurotic depress. } \\
\text { (d) Psychoneurosis } \\
\text { (e) Other } \quad \text {. }\end{array}$ & $\left.\begin{array}{l}0.91 \\
0.54 \\
0.62 \\
1 \cdot 24 \\
2 \cdot 65 \\
0 \cdot 15 \\
0.87 \\
2 \cdot 76 \\
2 \cdot 47\end{array}\right\} 12 \cdot 20$ & $\left.\begin{array}{l}= \\
- \\
= \\
= \\
\overline{0.06}\end{array}\right\}$ \\
\hline $\begin{array}{l}\text { F. Diseases } \\
\text { of } \\
\text { Nervous } \\
\text { System, } \\
\text { etc. }\end{array}$ & $\begin{array}{l}\text { 1. Vascular lesions } \\
\text { 2. Inflammatory Disease } \\
\text { of C.N.S. } \\
\text { 3. Epilepsy } \\
\text { 4. Diseases of eye } \quad \ldots \\
\text { 5. Diseases of ear } \quad \ldots \\
\text { 6. Others } \quad \text {. } \\
\text {. }\end{array}$ & $\left.\begin{array}{l}2 \cdot 51 \\
0 \cdot 87 \\
0 \cdot 51 \\
1 \cdot 05 \\
0 \cdot 54 \\
1 \cdot 78\end{array}\right\} 7 \cdot 26$ & $\left.\begin{array}{l}6.08 \\
0.50 \\
\overline{0.22} \\
-\end{array}\right\} 6.81$ \\
\hline $\begin{array}{l}\text { G. Circula- } \\
\text { tory } \\
\text { Diseases }\end{array}$ & $\begin{array}{l}\text { 1. Rheumatic heart .. } \\
\text { 2. Arteriosclerotic heart: } \\
\text { (a) Coronary arteries } \\
\text { (b) Other } \\
\text { 3. Hypertensive disease: } \\
\text { (a) With heart disease } \\
\text { (b) Without heart } \\
\text { disease } \\
\text { 4. Diseases of arteries } \\
\text { 5. Diseases of veins .. } \\
\text { 6. Other .. }\end{array}$ & $\left.\begin{array}{l}0 \cdot 54 \\
4 \cdot 98 \\
6 \cdot 03 \\
1 \cdot 82 \\
2 \cdot 91 \\
1 \cdot 78 \\
1 \cdot 09 \\
1 \cdot 16\end{array}\right\} 20 \cdot 31$ & $\left.\begin{array}{r}0 \cdot 89 \\
22 \cdot 10 \\
2 \cdot 85 \\
1 \cdot 28 \\
0 \cdot 95 \\
0 \cdot 56 \\
0.61 \\
1 \cdot 62\end{array}\right\} 30 \cdot 86$ \\
\hline $\begin{array}{l}\text { H. Respira- } \\
\text { tory } \\
\text { Diseases }\end{array}$ & $\begin{array}{l}\text { 1. Influenza } \\
\text { 2. Pneumonia } \\
\text { 3. Bronchitis: } \\
\text { (a) Bronchitis with } \\
\text { emphysema } \\
\begin{array}{l}\text { (b) Other } \\
\text { 4. Bronchiectasis }\end{array} \\
\text { 5. Other } \quad \cdots \\
\text {. }\end{array}$ & $\left.\begin{array}{r}0.04 \\
13.59 \\
1.74 \\
0.69 \\
0.76\end{array}\right\} 16 \cdot 82$ & $\left.\begin{array}{l}0.89 \\
2 \cdot 85 \\
4 \cdot 58 \\
1 \cdot 23 \\
0 \cdot 61 \\
0 \cdot 50\end{array}\right\} 10.66$ \\
\hline $\begin{array}{l}\text { I. Digestive } \\
\text { Diseases }\end{array}$ & $\begin{array}{l}\text { 1. Ulcer of stomach } \ldots \\
\text { 2. Ulcer of duodenum } \\
\text { 3. Gastrojejunal ulcer.. } \\
\text { 4. Hernia } \\
\begin{array}{lll}\text { 5. Other } & \ldots & \ldots\end{array}\end{array}$ & $\left.\begin{array}{l}1 \cdot 78 \\
3 \cdot 49 \\
0 \cdot 11 \\
0 \cdot 11 \\
1 \cdot 20\end{array}\right\} 6 \cdot 68$ & $\left.\begin{array}{l}1 \cdot 34 \\
1 \cdot 40 \\
\overline{0 \cdot 17} \\
2 \cdot 51\end{array}\right\} 5 \cdot 41$ \\
\hline $\begin{array}{l}\text { J. Genito- } \\
\text { urinary } \\
\text { Diseases }\end{array}$ & $\begin{array}{l}\text { 1. Nephritis } \\
\text { 2. Hyperplasia of prostate } \\
\text { 3. Other } \quad \ldots \quad \ldots\end{array}$ & $\left.\begin{array}{l}0 \cdot 33 \\
0 \cdot 25 \\
0 \cdot 44\end{array}\right\} 1 \cdot 02$ & $\left.\begin{array}{l}1 \cdot 56 \\
0 \cdot 11 \\
0 \cdot 22\end{array}\right\} 1 \cdot 90$ \\
\hline K. Skin & $\begin{array}{lll}\begin{array}{l}\text { Occupational } \\
\text { dermatitis }\end{array} & & \\
\text { 2. Other } & \ldots & \ldots\end{array}$ & $\left.\begin{array}{l}0.11 \\
0.47\end{array}\right\} 0.58$ & $-\}$ \\
\hline
\end{tabular}

TABLE IV (continued)

\begin{tabular}{|c|c|c|c|c|}
\hline \multicolumn{3}{|c|}{ Disease Group } & $\begin{array}{l}\text { Retirements } \\
\text { (per cent.) }\end{array}$ & $\underset{\text { (per cent). }}{\text { Deaths }}$ \\
\hline $\begin{array}{l}\text { L. Loco- } \\
\text { motor } \\
\text { System } \\
\text { Diseases }\end{array}$ & \multicolumn{2}{|c|}{ 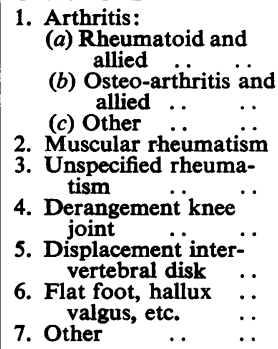 } & $\left.\begin{array}{l}1.38 \\
3.12 \\
1.71 \\
0.94 \\
0.65 \\
0.33 \\
0.87 \\
0.62 \\
0.65\end{array}\right\} 10.28$ & $\left.\begin{array}{l}- \\
\overline{0.06} \\
- \\
- \\
- \\
- \\
-\end{array}\right\} 0.06$ \\
\hline Violence & $\begin{array}{l}\text { 1. Accident } \\
\text { 2. Suicide }\end{array}$ & $\begin{array}{ll} & \cdots\end{array}$ & $\stackrel{2 \cdot 18}{-}\} 2 \cdot 18$ & $\left.\begin{array}{l}5 \cdot 13 \\
2 \cdot 34\end{array}\right\} 7 \cdot 48$ \\
\hline \multicolumn{2}{|c|}{ Ill-Defined, Senile, etc. } & . & 0.73 & 一 \\
\hline Congenital & . & . & 0.04 & 0.06 \\
\hline \multicolumn{2}{|c|}{ Multiple Codings } & . & $8 \cdot 80$ & 一 \\
\hline Total & .. & . & 100 & 100 \\
\hline
\end{tabular}

With the numbers available, any age-specific breakdown by cause and occupation is hardly practicable; but it is possible to compare the rates of invaliding and death in the two occupational groups already labelled as "active" and "sedentary". Table V shows the age-specific death and retirement rates in

\section{TABLE V}

ILL-HEALTH RETIREMENTS AND DEATHS AMONG "ACTIVE" AND "SEDENTARY" WORKERS (ALL CAUSES) (Rates per 1,000 workers per year)

\begin{tabular}{|c|c|c|c|c|c|c|c|c|}
\hline \multirow{4}{*}{$\underset{\text { (yrs) }}{\text { Age }}$} & \multicolumn{8}{|c|}{ Workers } \\
\hline & \multicolumn{4}{|c|}{ Sedentary } & \multicolumn{4}{|c|}{ Active } \\
\hline & \multicolumn{2}{|c|}{ Retirements } & \multicolumn{2}{|c|}{ Deaths } & \multicolumn{2}{|c|}{ Retirements } & \multicolumn{2}{|c|}{ Deaths } \\
\hline & No. & Rate & No. & Rate & No. & Rate & No. & Rate \\
\hline $\begin{array}{l}25-34 \\
35-44 \\
45-54 \\
55-59\end{array}$ & $\begin{array}{r}57 \\
96 \\
255 \\
215\end{array}$ & $\begin{array}{r}0.95 \\
1.62 \\
4.82 \\
11.90\end{array}$ & $\begin{array}{r}34 \\
94 \\
273 \\
181\end{array}$ & $\begin{array}{r}0.57 \\
1.58 \\
5.16 \\
10.02\end{array}$ & $\begin{array}{l}119 \\
212 \\
805 \\
994\end{array}$ & $\begin{array}{r}1.06 \\
1.82 \\
7.93 \\
23.95\end{array}$ & $\begin{array}{r}45 \\
154 \\
547 \\
464\end{array}$ & $\begin{array}{r}0.40 \\
1.32 \\
5.39 \\
11.18\end{array}$ \\
\hline Total & 623 & $3 \cdot 27$ & 582 & 3.06 & 2,130 & $5 \cdot 73$ & 1,210 & $3 \cdot 25$ \\
\hline
\end{tabular}

these two groups; it can be seen (as in Fig. 2) that, although the death and retirement rates for "sedentary" workers go up in step both with each other and with the death rate among "active" staff, the retirement rate among the "active" workers diverges rapidly, at ages over 45 , from the corresponding "sedentary" rate. To find the reasons for this divergence, we can split up the retirements by cause to see how much of the difference between the total age-standardized retirement rates is due to particular systematic disease groups. The result is shown in Fig. 3, where it is obvious that the most important 


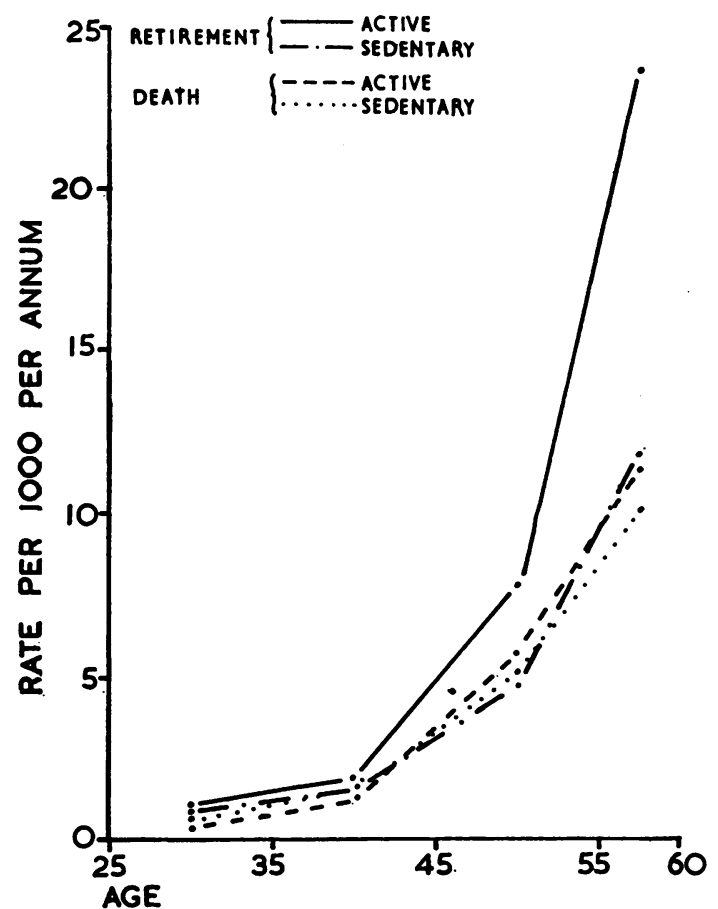

FIG. 2.-Ill-health retirements and deaths among "active" and "sedentary" workers (all causes) per 1,000 per annum, by age.

contributions to the divergence between "active" and "sedentary" workers are made by diseases of the circulatory, respiratory, and locomotor systems. There is little difference, on the other hand, between the invaliding rates from disorders of the central nervous system in the two groups.

ORDER DISEASE GROUP PER CENT.

\begin{tabular}{|c|c|c|}
\hline I & Cireulatory & 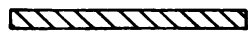 \\
\hline 2 & Resplratory & ل1/10101010 \\
\hline & Locomotor & תه \\
\hline & Tuberculosis & סصם \\
\hline s & Digestive & $\nabla$ \\
\hline 8 & Neoplesms & $\nabla$ \\
\hline 7 & Allergk, metobolic etc. & $\Delta$ \\
\hline & All other diseases & $\Delta$ \\
\hline & Aceidents and violence & 8 \\
\hline
\end{tabular}

FIG. 3.- Relative importance of causes of differences in invaliding rates between "active" and "sedentary" workers.

Table IV has shown the main components of these groups of diseases and suggests the likely explanation of the disparity in their effect on invaliding in the two types of staff. Within the three disease groups mentioned above, the main specific causes of retirement are arteriosclerotic heart disease, hypertension, bronchitis, and arthritis. All of these cause physical rather than mental disability. Mental illnesses, and diseases of the central nervous system which are largely vascular in origin, seem to be equally common as causes of retirement in the two groups. The reason is not far to seek. A clerk with arteriosclerotic disease of the heart or chronic bronchitis of moderate severity can perform his sedentary duties satisfactorily; but a postman with the same disability cannot climb stairs or cycle up hills with a load of letters and parcels. When, on the other hand, either suffers a severe cerebrovascular haemorrhage, the clerk is just as much incapacitated as the postman and the retirement rates from this cause are much the isame in these two occupations.

Table VI shows the difference in the age-specific sickness absence rates found in the sample survey for postmen, who form the bulk of the more active "outdoor" group, and other men employed mainly on sedentary duties. The disparity between these two sets of rates can be expressed as an active: sedentary ratio and contrasted, as in Fig. 4, with similar ratios

TABLE VI

AGE-SPECIFIC SICKNESS ABSENCE RATES IN POSTMEN AND OTHERS

(Mean number of days lost per man per annum)

\begin{tabular}{c|c|c|c}
\hline $\begin{array}{c}\text { Age } \\
\text { (yroup) }\end{array}$ & $\begin{array}{c}\text { Postmen } \\
\text { (Active) }\end{array}$ & $\begin{array}{c}\text { Others } \\
\text { (Sedentary) }\end{array}$ & $\begin{array}{c}\text { Active: Sedentary } \\
\text { Ratio }\end{array}$ \\
\hline $25-34$ & $13 \cdot 7$ & $9 \cdot 4$ & $1 \cdot 46$ \\
$35-44$ & $15 \cdot 7$ & $11 \cdot 6$ & $1 \cdot 35$ \\
$45-54$ & $18 \cdot 7$ & $13 \cdot 3$ & $1 \cdot 41$ \\
$55-59$ & $25 \cdot 1$ & $16 \cdot 7$ & $1 \cdot 50$ \\
\hline
\end{tabular}

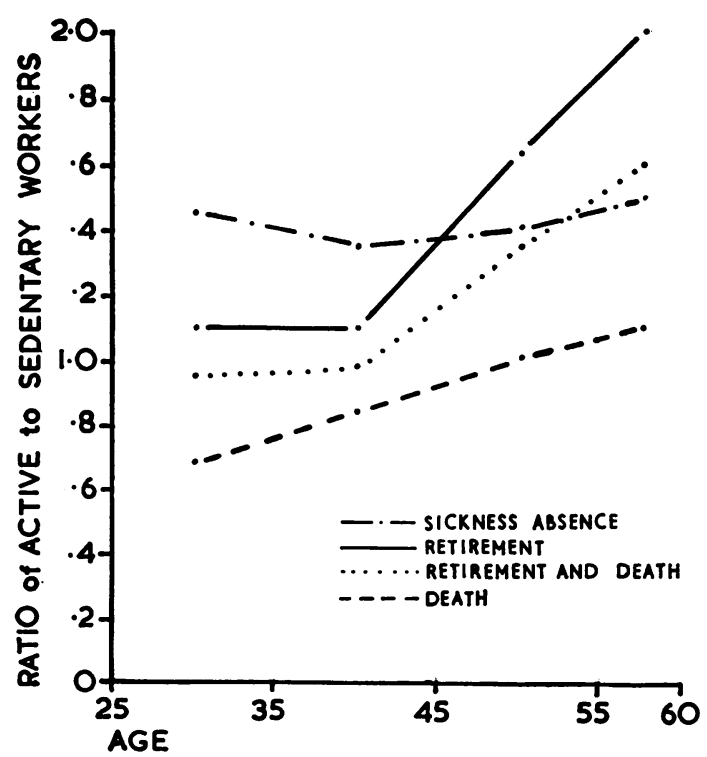

FIG. 4.- Ratio of sickness absence, ill-health retirements, and death rates in "active" and "sedentary" workers, by age. 
for ill-health retirement and death, either separately or together.

Although sickness absenteeism is consistently higher among the physically "active" staff at all ages, the measure of the relative incidence of serious disease given by the combined death and retirement rate confirms that there is a 50 per cent. excess in occupational disability due to disease or injury among the older "active" workers.

\section{SUMMARY}

A survey has been made of the causes both of retirement due to ill-health and of death before retirement at 60 years of age among the male established staff of the General Post Office during the period 1949 to 1952 inclusive. Where appropriate, the rates of invaliding and death have been compared with the results of a sample survey of sickness absence conducted among certain groups of G.P.O. staff in the London area during the period mid-1948 to mid-1951. The analysis of the data suggests that:

(1) The age-specific rates for sickness absence, ill-health retirement, and death rise appreciably after the age of 45 . Of the three, the retirement rate appears to be the most sensitive indicator of the effect of ageing on the incidence of occupationally disabling injury or disease.
(2) At current rates, some 27 per cent. of Post Office employees aged 25 (a selected group with death rates usually below those of the general population) may be dead or chronically incapacitated before they reach the age of 60 .

(3) The apparent relative numerical importance of different groups of disorders depends on the index of labour wastage used; but the respiratory diseases rank high as a cause of absence, invaliding, and death. Neoplasms and coronary disease of the heart, on the other hand, usually appear as causes of death rather than as major causes of sickness absence or premature retirement. A detailed account is given of the proportionate contributions made by particular disorders to the total wastage by death and ill-health retirement.

(4) A comparison of the death and retirement rates among two groups of workers whose jobs make different physical demands, shows that the gross disparity between them in ill-health retirement is due to excessive rates for diseases of the respiratory, cardiovascular, and locomotor systems among the older manual workers. Occupational disability as measured by sickness absence and total ill-health retirement and death rates appears to be 50 per cent. higher among the older "active" workers between 45 and 60 years of age.

We are grateful to Dr. W. E. Chiesman, Treasury Medical Adviser, for permission to publish this paper. We are also indebted to members of the medical and clerical staff of the Treasury Medical Service for their help and to Miss Sheila Hodgson for drawing the diagrams. 